\title{
Investigating Structural Relation of Organizational Trust and Organizational Citizenship Behavior to Intellectual Capital at State Universities in the West of Iran
}

\author{
VahidKianfar \\ PhD Student of Education Administration at the University of Isfahan \\ Seyyed Ali Siadat \\ Associate Professor of Education, University of Isfahan \\ Reza Hoveida \\ Assistant Professor of Education, University of Isfahan \\ Ahmad Abedi \\ Assistant professor of Education, University of Isfahan \\ Accepted: August 11, 2013 Published: Sep 06, 2013 \\ Doi:10.5296/ijld.v3i4.4248 URL: http://dx.doi.org/10.5296/ijld.v3i4.4248
}

\begin{abstract}
This study attempts to investigate the structural relation of organizational trust and organizational citizenship behavior (OCB) with intellectual capitalat medical and non-medical state universities in the west of Iran. Data collection is carried out by employing the questionnaire of organizational trust based upon Mayer and Davis's (1999) model, the questionnaire of organizational citizenship behavior based upon the model proposed by Podsakoff et al. (2000), and the questionnaire of Bontis' (2000) modelof intellectual capital. The statistical population comprises of 352 full-time faculty members of the above-mentioned universities. The findings revealed that the correlation between organizational trust, organizational citizenship behavior with intellectual capital is positive and significant and the structural equations modeling test shows that the proposed model for prediction of intellectual capital based upon organizational trust and organizational citizenship behavior corresponds to the collected data and organizational trust and organizational citizenship behavior have a positive, significant influence on intellectual capital.Besides, the square of multiple correlations for intellectual capital was measured 0.42. In other words, in this model, organizational trust and organizational citizenship behavioraccount for 42 percent of the variance of intellectual capital. The findings reveal that improving organizational trust and organizational citizenship behavior among the faculty members of the medical and non-medical state universities in the west of Iran leads to the growth of intellectual capital.
\end{abstract}

Key words: organizational trust, organizational citizenship behavior, intellectual capital, state universities in west of Iran

\section{Introduction}

In institutional sphere, trust is a fundamental factor in the formation of social relations. It, furthermore, is a positive atmosphere that leads the institutional interactions towards an optimizing paradigm. Development of positive relationships between the managerial and operational segments of an organization would result in preserving and fostering 
organizational citizens who are ready to go beyond their stipulated duties. Studies show that organizations arelikely toincrease the quality ofintellectual capitalthroughinterventionssuch as organizational citizenship behavior and trust in a way that by enhancing these variables, a higher levelofintellectual capitalin the organizations can be hoped. Various researches (Shirazi et al., 2012; Suciu, P icioruş \&Imbrişcă, 2012; Bolino et al., 2002) showed that the development of organizational trust can cause to the enhancement of organizational citizenship behavior on the part of the employees.

Erturk (2007) suggests that the trust of employees in their superordinatehas positive and significant relations with the level of organizational citizenship behavior and, moreover, this trust in superordinate would moderate the relations between organizational justice andorganizational citizenship behavior. Cabrita and Bontis (2008) believe that trust between employees and human capital, between trust for management and development of structural capital and between institutional trust and customer's capital has positive relations. Bontis (1999) suggested that organizational trust and culture play the role of variables in the formation of human capital. The present study, therefore, for its basis has presupposed the relation between organizational trust, organizational citizenship behavior and human capital in Higher Education System. The above relation, however, will be tested in the given statistics of medical and nonmedical state universities in the west of Iran.

Figure 1. is the conceptual model of the relationship between the variables that are followed in the present article :

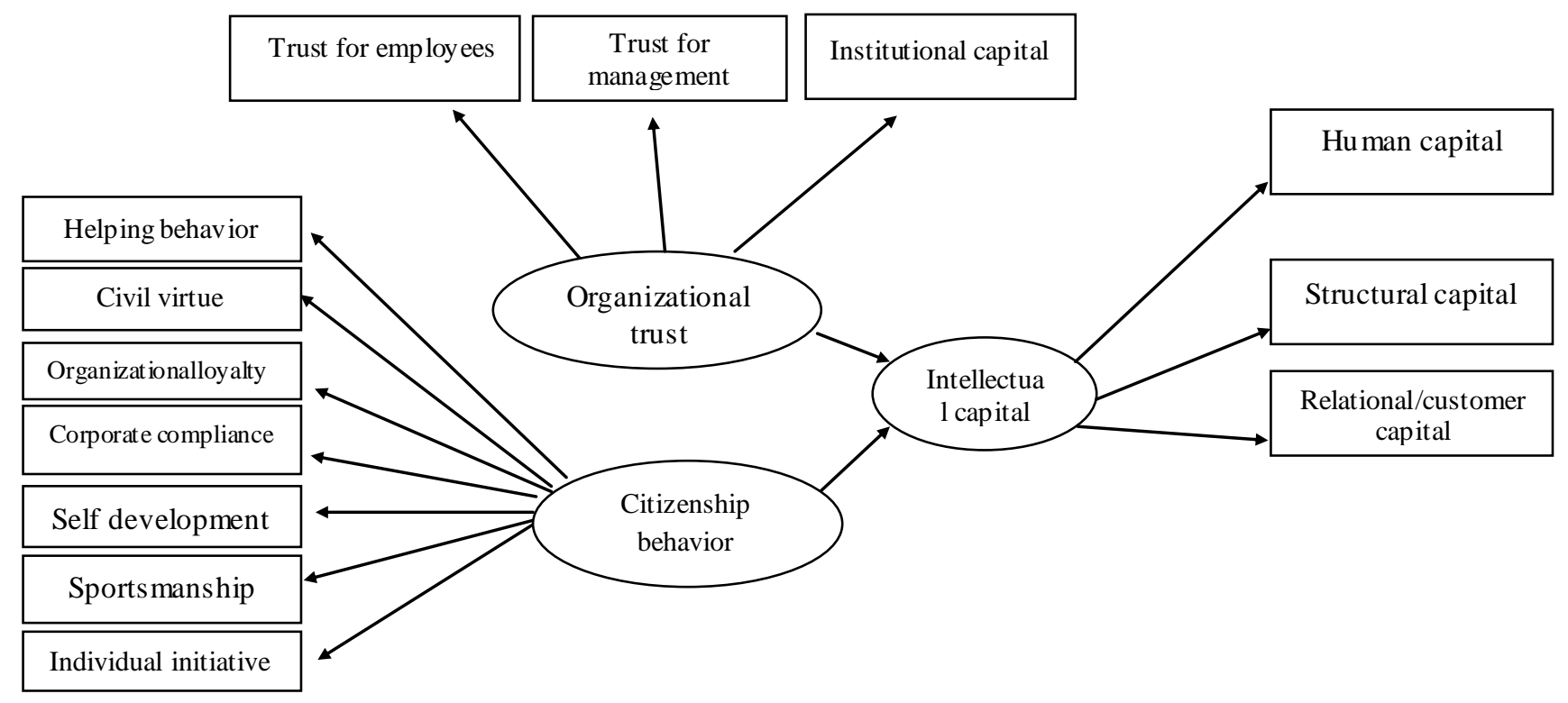

Figure 1. The Proposed Conceptual Model of the Relations between Research Variables

\section{Organizational trust}

\section{Theoretical Frame work}

Trust in an organization designates a climate in which the employees trust the senior managers' decisions and, on the other hand, the management board relies on the commitment, skill and knowledge of the employees. From this perspective, trust is a psychological state in which peopleareconfident of the results of their work, without any prediction of such results; this characteristic, thus to speak, has associated trust with innovation and creativity (O'Brien, 2003).

Mishra (1996) regards trust as a multidimensional concept that denotes desire of a person to vulnerability and fragility against another person; a desire that is due to four aspects: 1) belief 
in intention and consideration of partner exchange; 2) belief in competence and capability; 3) belief in reliability; 4) belief in clarity and openness. Schoornan, Mayer and Davis (2007) believe that trust is actually a mechanism forreducing negotiation risk, so that if confidence were dominantinall aspects of theorganization, the levelof risk anddanger that people have to tell the organizational truth would diminish. Elison and Fierstone (1974) definetrust as the transfer of resources to other people hoping that they act uponso as to diminish the negative results to the least level and therefore dependency to the goals would become possible.Galford\&Drapeau (2007) recognize three types of trust in an organization: 1 . Organizational trust by which the organization's policies will be fulfilled, the way they have been initially defined. 2. Strategic trust, i.e. trust in mission, strategy and ability to success. Personal trust or the trust that subordinateshave for their managers so as to consider their interest objectively. From another perspective, however, organizational trust is both interpersonal and inter-institutional. Interpersonal trust, thus to say,consists of trust for employees (among employees) and trust for managements (between managers and employees), which requires the three factors of competency, benevolence and assurance ability (Mayer \& Davis, 1999). From this perspective, organizational trust is more applied to the positive expectations of individuals and those demands that the organization's members have over the competency, benevolence and ass urance ability of one another and their managers. Institutional trust, moreover, designates a trust between an organization and individuals. Yilmazand Atalay(2009) by collecting various definitions of different authors (such as Mayer et al., 1995; Child and Mollering, 2002;Wech, 2002; Kickul et al., 2005) and the consequences of organizational trust, define it so:"The tendency of employees tosafety from the acts ofemployers upon those decisions they (employers) make and expect their subordinates follow in orderto providea safework environment. The result of this trust isthe development of positive emotional relationsbetweenemployersandemployees that would lead to positive interactions between the two; moreover, this would facilitate a just behavior in the organizations" (p. 344).

\section{Organizational citize nship behavior}

There is a strong belief among management scholars and owners ofmanufacturing and service foundations that successful organizations need employees, who beyond the stipulated requirements and roles, look forward to creativity and initiatives. Chester Barnard (1930) once considered the phenomenon of civil behavior and called it 'extra role behavior'. After Barnard, Katz and Kuhn (1966) understood that there were behaviors in the organization that had significant impact on effectiveness of the organization. With a slight deviation from Barnard's, they named these behaviors as 'super role behaviors'.

Although Barnard, Katz and Khun due to their establishment of extra role behavior are assumed as the predecessors of the concept of organizational citizenship behavior, the major investigations over this concept have been started since 1983, when Organ and Betman named this concept the same name (organizational citizenship behavior). Izhar (2009) defines organizational citizenship behavior as a set of behaviors that are not formal requirements of an organization, butthey neverthelesshelp the effectiveness of the organization forward.Vonday(2010) in his definition of organizational citizenship behavior defines it as discretionary. These behaviors are the actions that support major functions and in themselves, moreover, they are optional, since they are not parts of a person's main task (Erhart) (Moorman \& Blakely, 1995).

Components of organizational citizenship behavior that in fact play a defining role for this concept, based on Podsako ff et al.'s seven-factor model, are:

A. Helping Behavior (to helpcolleaguesto perform well thejobduties)

B. Civil Virtue (intentionalparticipationin the serviceof organizational goals) 
C. Organizational Loyalty (commitment to the organizational goals)

D. Corporate Compliance (proper and self-directing ways in problem solving)

E. Self Development (attempts to updatethe individual'sk nowledgeandskills)

F. Sportsmanship (holding justice in organizational ups and downs)

G. Individual Initiative (conscientious nessand self-controlinadminis trativetasks)

\section{Intellectual capital}

International Federation of Accountants (IFAC) (1998) has defined intellectual capital as the 'knowledge assets' of a company. It has applied it to the knowledge assets of an organization that play significant role in developing the competitive position of an organization through adding value for the key shareholders. According toStewart(1997), intellectualcapitalcan be considered and defined asknowledge, skills,competencies andabilitiesthatcreatewealthand also help to generatevaluableoutputs. Bontis (1996) believes that intellectual capital is an ambiguous and complicated term, by understanding and exploiting of which, however, there can be brought about new resources. By the use of these resources, so to speak, the organization can compete. Bontis(1998) in another definition of the term maintains that intellectual capital is an attempt to make an effective use of knowledge (final product) against data (raw material). Bontis in his later studies of the theoretical concept of intellectual capital furthered the term into a three-dimensional concept: human capital, structural capital and relational or customer capital (Bontis\&Sernko, 2009).

\section{Human Capital}

Human capitalrepresents theknowledgestock ofanorganization(Bontiset al., 2000), whichconsists ofcompetencies, tacit experiences andknowledge-based employeesinthe whole organization (Bontis\&Sernko, 2009). This kind of capital, thus to say, isindicativeof theperceptionof theiremployees (especially the employee's knowledge). This capital represents capabilities of the employees asconsistent source ofrenewaland innovationfor the organization; moreover, they have theability tounderstandbusinessissuesandareableto exploit the experiences they gain(Longo, 2007).

\section{Structural capital}

Structural capital includes the accumulated knowledge in the body of an organization that refers to the existing structures and processes of the organization. Employees use them and in this way and then they put their knowledge and skills in practice (Vargauwen\&VanAlem, 2005). Structural capital consists of a setaccumulated knowled ge in the body of an organization where it includes factors such as values, processes, digital date, policies and procedures (Binney et al., 2007).

\section{Custome r Capital}

This capital presses on all sources that are associated with inter-institutional relations. In this frame, certain cases are categorized; cases such as all communication networks and agreements with institutional stakeholders (especially customers), distinguishing features like brand, and those variables that organizational stakeholders have from the organization. In this variable, moreover, intellectual capital has been insisted on for all communications and interactions that thus lead to a strong and stable customer relationship, and certain other cases such as contracts and agreements, customers' satisfaction and loyalty (Khavandkar et al., 1388).

Sanchez and Elena (2006) put this variable in higher education as recourses related to external relations of organization such as customers, suppliers, research and development groups and governments. According to these writers, customer capital is similar to a relation that consists of activities and relations between a university and nonacademic members, firms, non-beneficial organizations, public authorities, local states, and society in its full sense. 


\section{Methodology}

The present study is a correlational research and its statistical population includes all full-time faculty members of medicaland non-medical state universities in the west Iran (Lorestan, Ilam, Kermanshah, and Hamedan). The population was 1972 peoplen in academic year of 2012-2013, out of which a sample of 352 was selected using stratified sampling method. Out of this amount, 327 people answered the questionnaires. Data collection was carried out by employing the questionnaire of organizational trust based upon Mayer and Davis's (1999) model, the questionnaire of organizational citizenship behavior based upon the model proposed by Podsakoff et al. (2000), and the questionnaire of Bontis's (2000) model of intellectual capital. Data was graded based on Likert scale, scoring grade ' 1 ' option as "totally disagree" and grade ' 5 ' option as "totally agree". Using Cronbach's alpha, final coefficients of questionnaires of organizational trust, organizational citizenship behavior and intellectual capital were given respectively as (/86), (/84) and (/88).

\section{Statistical findings}

Research hypothesis: structural model of the relationship between organizational trust and citizenship behavior and intellectual capital in state universities of the west of Iran has fit with the data. Analysis of the statistical data resulted from the sample show that there is a positive and significant correlation between the three main variables. Table 1 shows the mentioned correlation coefficient.

Table 1. Pearson correlation between organizational trust and citizenship behavior with intellectual capital in state universities in west Iran.

\begin{tabular}{|l|c|c|l|l|}
\hline Source & Frequency & r & $\begin{array}{l}\text { Effect } \\
\text { Size }\end{array}$ & $\begin{array}{l}\text { Significance } \\
\text { Level }\end{array}$ \\
\hline Organizational Trust and OCB & 327 & $0 / 52$ & $0 / 26$ & $0 / 001$ \\
\hline $\begin{array}{l}\text { Organizational Trust and } \\
\text { Intellectual Capital }\end{array}$ & 327 & $0 / 75$ & $0 / 56$ & $0 / 001$ \\
\hline OCB and Intellectual Capital & 327 & $0 / 60$ & $0 / 36$ & $0 / 001$ \\
\hline
\end{tabular}

As shown in Table 1 , observed $\mathrm{r}(\mathrm{p} \leq 0 / 001)$ shows a significant and positive correlation between organizational trust and citizenship behavior and intellectual capital of state universities in the west of Iran. Effect size between organizational trust and citizenship behavior is $0 / 26$, between organizational trust and intellectual capital is $0 / 56$, and between citizenship behavior and intellectual capital is $0 / 36$.

In the model of structural equation the main hypothesis is assumed in a way that citizenship behavior and the organizational trust factor asexogenouslatent variables have effects on intellectual capital as an endogenous latent variable. The conceptual model of the research hypothesis is shown in Fig. 2. 


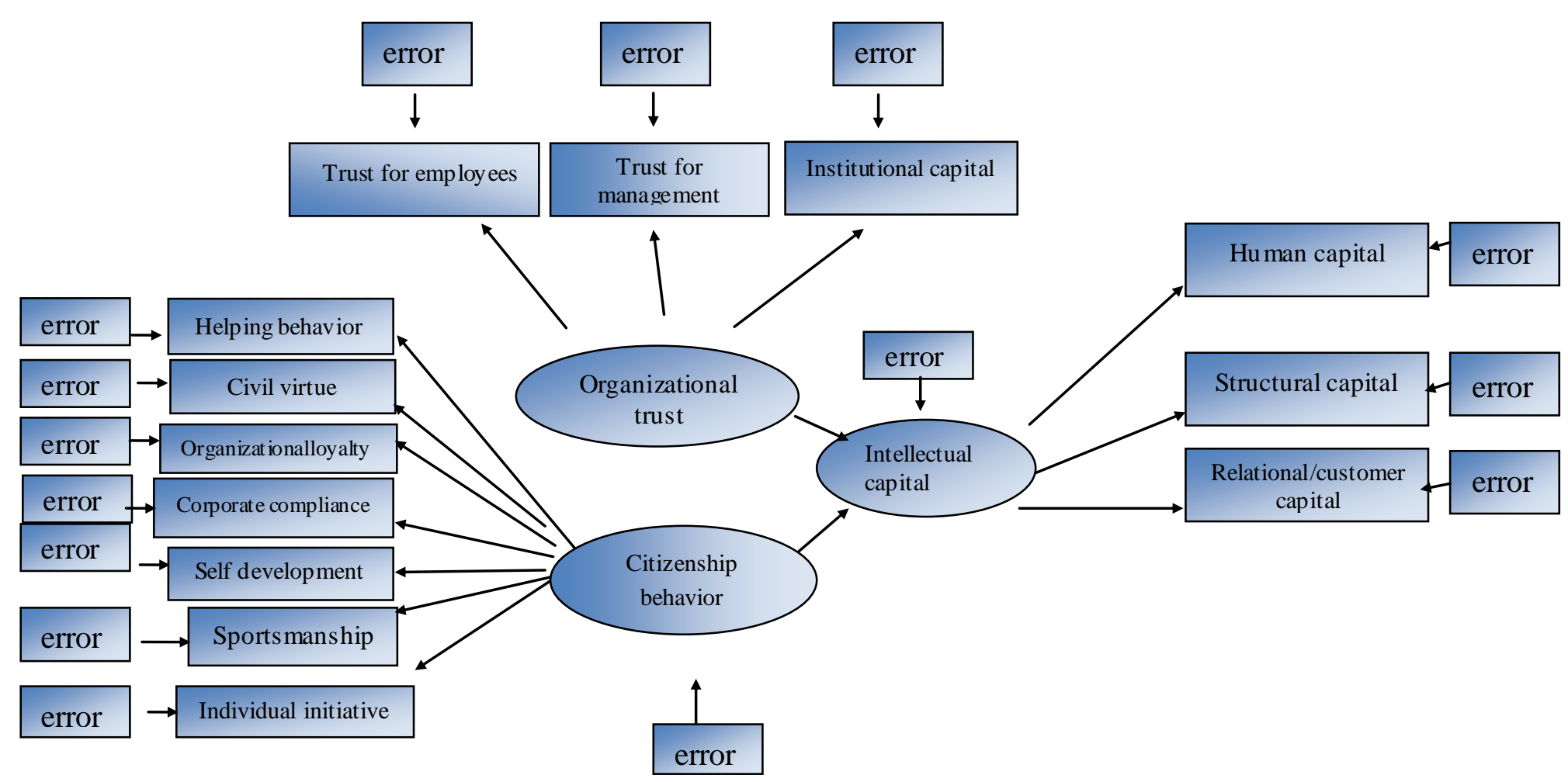

Figure 2. Conceptual Model of the Main Hypothesis of the Research

Table 2 represents the study of overall fitness indices for this model.

Table 2. Overall fitness Indices for Main Hypothesis

\begin{tabular}{|c|c|c|c|c|c|c|c|c|}
\hline \multicolumn{9}{|c|}{ Overall Fit Indices } \\
\hline \multicolumn{3}{|c|}{ Economical } & \multicolumn{2}{c|}{ comparative } & \multicolumn{3}{|c|}{ absolute } \\
\hline RMSEA & PCFI & PNFI & CMIN/DF & CFI & TLI & P & DF & CMIN \\
\hline $0 / 67$ & $0 / 68$ & $0 / 67$ & $3 / 62$ & $0 / 87$ & $0 / 87$ & $0 / 0001$ & $0 / 31$ & $3 / 62$ \\
\hline
\end{tabular}

As shown in table 2, the value of chi-square is significant and the value of chi-square $(3 / 62)$ shows that the model is acceptable. The value of comparative indices, TLI and CFI (0/87 and 0/88), shows that the model corresponds with the data. The value of the indices PNFI and PCFI $(0 / 67$ and $0 / 68)$ shows that the economy of the model has been observed appropriately. The value $0 / 67$ for the index RMSEA indicates that the model generally has fit with the data and is confirmed.

Table 3 gives a brief summary of results, such as structural coefficient, which are related to the details of the model.

Table 3. Summary of estimated parameters for the main hypothesis

\begin{tabular}{|l|c|c|c|}
\hline \multicolumn{1}{|c|}{ Parameters } & $\begin{array}{c}\text { Standard } \\
\text { estimation }\end{array}$ & Critical value & $\begin{array}{l}\text { Significant } \\
\text { level }\end{array}$ \\
\hline $\begin{array}{l}\text { Organizational trust } \\
\text { intellectual capital }\end{array}$ & $0 / 51$ & $2 / 58$ & $0 / 01$ \\
\hline $\begin{array}{l}\text { Citizenship behaviour } \\
\text { intellctual capital }\end{array}$ & $0 / 47$ & $2 / 04$ & $0 / 04$ \\
\hline
\end{tabular}

As seen in table 3, organizational trust has positive and significant effect on intellectualcapital, and in a significant way it leads to the increase of intellectual capital. The factor of citizenship behaviorfurthermore has positive and significant effect on intellectual capital. Moreover, 
ssquared multiple correlation for intellectual capital was 42/0. In other words, 42 percent of the variance of the intellectual capital is accounted for in this model. This hypothesis is then confirmed; therefore, organizational trust and citizenship behavior together haveeffects on intellectual capital. Table 4 presents the results of the study of different key parameters from a statistical viewpoint.

Table 4. The Significant Study of Differences between Key Parameters of the Main Hypothesis

\begin{tabular}{|l|c|}
\hline \multicolumn{1}{|c|}{ Parameter } & $\begin{array}{c}\text { Critical } \\
\text { value }\end{array}$ \\
\hline $\begin{array}{l}\text { Organizational trust Intellectual capital Citizenship behavior } \\
\text { Intellectual capital }\end{array}$ & $0 / 48$ \\
\hline
\end{tabular}

As shown in table 4, there is no significant difference between the impact factor of organizational trust over intellectual capital and the impact factor of citizenship behavior over intellectual capital. In other words, organizational trust has much more effects on intellectual capital than citizenship behavior.

\section{Discussion :}

The presence of organizational capital in universities would bring about positive relationships in different arenas. The key point between the relation of organizational trust and intellectual capital is however implied in knowledge and the related concepts. Horizontal trust (trust for employees) will lead to the formation of a sort of dedicative relationship among the faculty members. By and large, moreover, this way they dedicate their tacit knowledge to their colleagues. Therefore, positive attitudes will be developed towards both colleagues and work; therefore, this knowled ge cause to the growth of both individual and organization at the same time. The faculty members' trust in university administrators would lead to the organizational change and development, since this trust brings about participation of individuals in different areas. This factor, too, makes the employees easily accept the organizational procedures and and adapt themselves to the dominant culture of the organization. This way, so to spe ak, the individual vs. organizational discrepancies will be put in safe. Vertical trust (trust for management) has another outcome for the organization and that is the facilitation in the formation of structural capital; because by reaching this sort of trust, the organization's policies and strategies are welcomed and well-supported by the employees. Institutional trust forms the trusty picture of the organization and there fore leads to the customers trust in the organization's procedures, guidelines and services. By and large, it can be understood that organizational trust greatly affects intellectual capital by facilitating inter-organizational relations and the surroundings, sharing knowledge and information, and supporting institutional mechanisms.

The components of OCB although are assumed as extra-role and-extra task expectations, they both can accelerate the formation of organizational trust and as independently they can increase the faculty members' commitment. These factors, therefore, will help team work in educational groups grow rapidly; these behaviors thus help the growth of human resources, especially in cases like cooperative behavior, self development, individual initiative and sportsmanship. To this end, factors like corporate compliance and organizational loyalty will contribute to the institutionalization of structural capital in universities. Civil virtue and organizational loyalty will transform the organizational capabilities from the part of employees to the climate; moreover, advertisement of the organizational characteristics of the universities for the customers will depict an appropriate image of the capabilities of the universities among them. Through the aforementioned components, the customer capital (relational) of universities will gradually boost. 


\section{Refrences :}

Binney, D. Guthrie, J, Boedker, C. \&Nagm, F. (2007). A framework for indentifying the intangible capital value of ITC investments. Paper for the 11th Pacific Asia Conferaance of Information Systems. Auckland, New Zealand, 3 - 6 July 2007.284-296.

Bolino, M. C., Turnley, W.H., \&Bloodgood, J. M. (2002). Citizenship behavior and the creation of social capital in organizations. Academy of Management Review. 27, 505-522. Bontis, N. (1998). Intellectual capital: an exploratory study that develops measures and models. Managing Decision. 36 (2), 63-76.

Bontis, N. (1999). Managing organizational knowledge by diagnosing Intellectual capital: framing and advancing the state of the field. International Journal of Technology Management. 18 (5/6), 433-62.

Bontis, N. (2000). Intellectual capital and business performance in Malaysian industries. Journal of Intellctual Capital. 1 (1), 85-100.

Bontis, N., \&Serenko, A. (2009). A casual model of human capital antecedents and consequents in the financial services industry. Journal of Intellectual Capital.10 (1), 53-69. Cabrita, M. R., \&Bontis, N. (2008) Intellectual capital and business performance in the Portuguese banking ind ustry. International Journal Technology Management. 43 (1-30), 212-237.

Ellison, C., \& Firestone, N.(1974). Development of interpersonal trust as a function of self-steem, Target status and Target style. Journal of Personality and Social Psychology. 29 (5), 655-663.

Erturk. A. (2007). Increasing organizational citizenship behavior of Turkish academicians: mediating role of trust in supervisor on the relationship between organizational justice and citizenship behavior. Journal of ManagerialPsychology. 22 (3), 257 - 270.

Galford, R. \&Drapeau, A. (2007). The trusted leader. See at: $\underline{\text { ww.quickmba.com. }}$

Izhar, O. (2009). Organizational citizenship behavior in teaching: the consequences for teachers. pupils and the school. International Journal of Educational Management. 23 (5), 375-389.

International Federation of Accountants (IFAC). (1998). The measurement and management of Intellecual capital. International Federation of Accountants.NewYork.

Khodavandkar, J., \&Khodavandkar, E. (1388). Management of intellectual capital, developemnet management, assessment models. Tehran: The Center of Industrial Education and Researches of Iran.

Longo, M. (2007). A multidimensional measure of employees, intangibles a managerial implementation of the tool. Management Research News. 30 (8), 548-569.

Mayer, R. C., \& Davis, J. H. (1999).The effect of the performance appraisal system on trust for management. A field quasi-experiment. Journal of Applied Psychology, 84 (1), 123-136.

Mishra, A. K. (1996). Organizational responeses to crisis: the centerality of trust in Keramer, R. $M$ \& Tyler, T. R. (ed), trust in organizations: 261 -287. Thousand aks, CA. Sage Publications.

Moorman, R., \&Blakley, G. (1995a). Individualism-collectivism as an individual difference of organizational citizenship behavior. Journal of Organizational Behavior. 16 (2), 127-142.

Moorman, R., \&Blakley, G. (1995b). Individualism-collectivism as an individual difference of organizational citizenship behavior. Journal of Organizational Behavior. 16 (2), 127-142. 
O'Brien, R. K. (2003). Trust: energy release for wining. Selected Proceedings of the thirty-fifth International Conference of Human Resources. (Venice-Italy): Special Issue of Human Resource Development Conference. (Trans. Babaei Z. M. et al.). Tehran: Ronas. 103-106.

Podsakoff, P. M. Mackenzie, S, B. Paine, J, B. and Bachrach, D, G. (2000). Organizational citizenship behavior, A critical Review of the theoretical and empirical literature and suggestion for future research. Journal of Management. 26 (3), 513-563.

Sanchez, M. P., \&Elenas, S. (2006). Intellectual Capital in universities improving transparency and internal management. Journal of Intellectual Capital. 7 (4).

Schoornan, F. D., Mayers, R. C., \& Davis, J. H. (2007). An integrative model of organizational trust: past, present and future. Academy of Management Review. 32 (2), 344-354.

Shirazi, A., Khodaverdian, E., \&Naeimie, M. (1391). The impact of organizational trust on organizational citizenship behavior; a case study of Gas Compnay of NorthenKhorasan. Journal of Transformation Management. 4 (7): 133-153.

Stwart, T. A. (1997).Intellecual capital: the new wealth of organization. Doubleday Icurrency.New York.?.

Suciu. M, C., Picioruş. L., \&Imbrişcă C. I. (2012). Intellectual capital, trust, cultural traits and reputation in the Romanian education system.The Electronic Journal of Knowledge Management. 10 (3), 223-235. Available online at:www.ejkm.com.

Vergauwen, P. VanAlem, F. (2005). Annual report Intellectual cap ital disclouresin the Netherlands, France and Germany. Journal of Intellectual Capital. 6 (1), 89-104.

Vondey, M. (2010). The relationships among servant leadership, organizational citizenship behavior, person- organization fit and organizational identification. International Journal of Leadership Studies. 6 (1), 3-27.

Yilmaz, A., \&Atalay, G. C. (2009). A theoretical analyze on the concept of trust organizational life. European Journal of Social Science.8 (2), 341-352. 